\title{
Socio-Psychological Problems and Socio-Educational Value in the Work of Shakarim Kudayberdiuly "Three Clarities"
}

\author{
I. R. Khalitova ${ }^{1} \&$ A. I. Altynbekov ${ }^{1}$ \\ ${ }^{1}$ National Pedagogical University named after Abay of the Republic of Kazakhstan, Almaty, Kazakhstan \\ Correspondence: A. I. Altynbekov, Turkestan, 161200, Kazakhstan. Tel: 7-701-320-59-58. E-mail: \\ Alpamys2008@mail.ru
}

Received: June 9, 2014 Accepted: July 4, 2014 Online Published: July 29, 2014

doi:10.5539/ass.v10n15p269 URL: http://dx.doi.org/10.5539/ass.v10n15p269

\begin{abstract}
Shakarim in the outset of his work openly expressed his view on this issue. He paid special attention to the problem of honor. In general, the concept of honor is concomitant to the notion of conscience; this is a theologico-philosophical term determining the features, quality and essence of human being. This is how honor is defined scientifically. "Honor is hidden feature of the person, it is a meta-concept in cognition of the world by Shakarim. This concept occupies special place in the philosophical treatise "Three clarities" as well as in the philosophical lyrics.
\end{abstract}

Keywords: clarity, honor, philosophy, nationalism, scientific, treatise Shakarim

\section{Introduction}

Formation of Shakarim Kudayberdiuly's worldview was initially influenced by education of his master, great Abay as well as his travels to the European cities such as Paris and Istanbul. Thinker and poet while traveling in these cities visited libraries, got familiar with works of scientists from ancient times till the XIX-th century, studied views of different trends of each school. Upon returning Shakarim produced voluminous philosophical, theological treaties. Such works as "Three clarities" and "Islam" revealed breadth and high degree of religious and philosophical knowledge of the thinker.

Since his youth, having received Islamic education, teachings of Quran, Tafsir, Fikh, and Khadis, Shakarim's outlook began to evolve on the basis of Islamic religion. Having studied principles and conditions of the Islamic religion he grew up as a scientist deeply comprehending theology. In his work "Conditions of Islam" he pointed out to principle of full compliance of each pronounced word and thought with the conditions of Sharia, and as a testimony he referred to the instances from Khadises and Quran. For the modern society, in which the role of religion is increasingly embodied, that work remains demanded.

\section{Main Part}

What was the goal of writing "Three clarities" which describes in details requirements of Sharia reflected also in his work "Conditions of Islam"? If one seeks for the genuine principles of existence only in religion then they should not be mixed with other words and views. So the question is why in the work a special deliberation was made on materialism and religion - two incompatible theories - in an attempt to analyze and examine separately their foundation and content. The main point is that Shakarim was far from religious fanaticism and preferred common sense, the power of logic, and clear perception of truth. Poet criticizes clerics which think shortsightedly or even do not think at all.

In the work "Three clarities" Shakarim taking seriously facts provided by "objectists" and "religionists" advances his own new views on soul. Here, "objectivists" stand closer to "materialists", so this current of thought pays more attention to form of the studied object not to its meaning. The main representatives of this current Auguste Komte provided arguments on positivists outlook which Shakarim reviewed in his works (Shakarim Kudayberdiuly, 2000).

The 19-th century was the time when the scope of knowledge was expanding due to such branches as positivism, materialism, existentialism. According to Konte, scientific cognition is the highest level of development of knowledge. The most precious branch of cognition is a scientific (positive) direction which is real, precise and useful. Comparing many utopist projects of the creation of the ideal society with precise concepts of physics, social 
sciences should reject utopia and begin studying exact facts of the social life, accurately describe them, systematize and collect them. Positivists deny philosophy as a system of required principles. Therefore, they believe that positive tasks of philosophy are generation of precise knowledge, descriptions, classification and systematization. Science should not answer the question why certain phenomena happen but rather limit itself to the question of how these phenomena happen; and eschewing investigations of genuine causes of the phenomena became of the basic postulates of positivism (Kont, 2006). This, in turn, has led to the insight into the essence of the subject and its soul.

In the XX-th century atheism and materialism blocked the development of the society. This especially affected psychology. Representatives of positivism, humanism and enlightenment, especially atheists and existentialists overlooked soul. As some researches argue, contemporary psychology takes as a method "science without soul" (Kenjatev, 2007). Contemporary psychology is focused on human brain. That's why contemporary psychology doesn't meet requirement its mission: it became a science about brain, not about spirit. Indeed, while for each religion the essential subjects are moods, spirit and heart, as Shumakher pointed out (1977), for those who are preoccupied with contemporary materialist sciences such concepts as 'soul' or 'mood' are insignificant ones. They perceive human being as simply an animal and are convinced that the truth is comprehended by mind, not by soul (Shakarim, 2008).

In his well known philosophical treatise Shakarim Kudayberdiuly who had a clear perception of such contradictions of emergence of the universe, revealed and widely discussed the problem of the soul. This work of Shakarim is a result of his searches and teaching of the previous period. The thinker by combining the theories widely spread in Europe that time showed them as a single science and provided his arguments. He spent thirty years of his life to have written this work. The main system of "Three clarities" was constructed around such philosophical questions as "Was the world created by some forces or did it evolve naturally? Is there life after human's death? What is a soul?" The scientist who studied creation of Shakarim B. Rahymjanov mentions the following view which Shakarim wanted to express in "Three clarities": "In Shakarim's opinion, no one phenomenon in the world happens sporadically. Every one phenomenon has its own certain cause. And that cause also has its own cause. So, in this way we can assume that the prime cause of everything is the Creator. This is for Shakarim the first clarity.

The second question is connected to that of soul. By ontological system advanced by Shakarim all things in the world do not disappear, they just change their form or transit to another state. Here, it has to be pointed out that Shakarim appeals to the achievements of natural sciences. Thus, if nothing disappears in this world but only is overall present, then there is no reason to say that the soul disappears. It means, in other words, the soul eternal and immortal. It lives forever only leaving its closes, means and body. The body transits to another state according to laws of biological and material world. It gets worn, dies and rots. So the idea of immortal soul constitutes the second clarity in the philosophy of Shakarim.

If a soul doesn't die and lives eternally then the main goal of the human's life becomes clear. This goal is not to think of the state of the body which lives only temporarily but of eternal life of soul, i.e. think about search of feeding the soul. A soul was created with special purity. Therefore, it should be kept in purity, avoiding impurity and always taking care of feeding it. This should, in Shakarim's opinion, constitute the main goal of human being. So, the third clarity in Shakarim's philosophy is expressed as follows: the food for the soul is conscience (Shakarim, 2008).

Shakarim in the outset of his work openly expressed his view on this issue. He paid special attention to the problem of honor. In general, the concept of honor is concomitant to the notion of conscience; this is a theologico-philosophical term determining the features, quality and essence of human being. This is how honor is defined scientifically. "Honor is hidden feature of the person, it is a meta-concept in cognition of the world by Shakarim. This concept occupies special place in the philosophical treatise "Three clarities" as well as in the philosophical lyrics.

Shakarim says: "In both lives the most needed thing is honor. Honor is satisfaction, kindness, honesty". Satisfaction, kindness, honesty are the best features of humankind. Because they are implied in the notion of honor this is a meta-concept. The question arises as to whether honor is a beginning of genetic meaning of human's description which was sent with Creator's ray?

There is an opinion that honor is an innate feature of human being who over time gets it or loses it: "Conscience as a prime moral motivation is an innate feature and it can, due to external influence, develop or die" (Gubskiy, 2007). Psychologists also argued similarly: "Conscience is not only a metaphor but also is perceived as "voice of God"; conscience is a voice of Universal Law, Highest Truth" (Apresyan, 2007). 
In the chapter "Conscience" the author writes: "The combination of satisfaction, justice and kindness yields what Muslims call "ujdan" and in Russian "sovest"”... I think there is no answer to the question about the origin of conscience. To my mind, conscience is a state of soul. A soul doesn't disappear, doesn't corrupt but contrary rises. So a soul needs a reason for rising, and it is conscience." As conscience is a state of soul we come to the conclusion that in both lives the "food of soul will not disappear. Researches of the thinker of conscience are very broad. He uses his ideas with respect to national issues.

Sh. Kudayberdiuly's article "On nationalism" was published in the journal "Abay" in 1918. It was his response to the article written by Mannap Turganbaev "Nationalism". He wrote: "I think, the term 'culture' arises from nationalism and nationalism gives rise to humanity". How can we prove it? We see nationalism and culture in highly developed Europe; are they human? I believe a nation couldn't ever benefit from self-esteem. And what is a reason of this? Although nationalism stimulates culture, it cannot stimulate pure heart; pure heart arises out of "Conscience that is, ability to see all people as brothers, wish all kindness, stand for justice. The truth is, if pure hearts unite humanity will prevail. Pure heart (conscience) can give what a nation (people) lacks." (Shakarim Kudayberdiuly, 1918). As we see from this assumption, the place of conscience is in pure heart which is the source of all good features of human being. That's why the thinker dreamed that there were many people with pure conscience. From this point of view, the problem that Shakarim Kudayberdiuly raised remains essential up to now.

The Shakarim Kudayberdiuly's philosophical and theological work embraces, in general, creation of the world, development, birth and death of all living in the world; the thinker constantly deals with complicated phenomena which happen around and seeks for answers to the main question as to who is the Master setting everything in motion.

He also tries to explain what Creation gives all who live in the world. Shakarim says: "There two different ways for people. One is: if a body dies a soul doesn't, it doesn't disappear; after death there will be life not like this one; therefore, people should not think of only this life but think of another life in order to be happy there as well. Another way is: everything that exists in the world emerged naturally in itself, nobody created the world and after death there will be no resurrection. The thinker indicates which way is right and which is not.

He provides five testimonies out of analysis of Europe of XVII-XIX centuries. He talks about atoms of which the world consists and which drive everything. Atoms combine in themselves by laws of attraction and create a body; they pass from one state to another and change; so things were not created as such. From this point the thinker testifying his ideas on soul begin talking about two lives and conscience. He argues that if a human being lives his life under the laws of conscience, honor, justice and does kind deals then he will be greatly rewarded. And conscience is a thing that is fully connected to the eternity of a soul.

Shakarim Kudayberdiuly in his "Three clarities" mentions such methods as magnetism, spiritism and telepathy to testify the existence of a soul. Magnetism is an influence exerted from the soul of one person on the soul of another person. My means of magnetism one can be forced to fall asleep and in such a spiritual state he can be asked about deals that he did or will be doing and in this way he can be influenced. Telepathy is a means by which one soul gets in contact with another soul in distance and affects it. The thinker pays special attention to spiritism and studies more works on spiritism. This is religious and philosophical school created by Allan Kardec. Those who do spiritism are called mediums. They talk about themselves as deliverymen who bring what spirits say to living people.

In "Thee clarities" the author reminded that spiritism was founded by a French Allan Kardec who lived in France in the XIX-th century. His work "The book of spirits" was published in Paris in 1863. The treatise consists of four books and thirty chapters. In this book the background of spiritism was described in detail and the notions of soul and spirit were examined. There are answers to more than one thousand questions about a soul in this book. It is very likely that during his trip to Paris Shakarim Kudayberdiuly got acquainted with this work; if even he didn't read it he might get enough information about it from his conversations with representatives of spiritism. Shakarim found similarities between Allan Kardec's contemplations of a soul and spirit and religion of Brahmanism.

For example, after death a soul passes to a certain animal and then moves in this sequence. "The doctrine of spirit is a highest degree of Christian thought about God's justice, code of human will, moral teaching of Christ, because they aren't alien to the religion" (Kardec, 1863). It is obvious that Kardec supported Christianity.

But Shakarim went further in his views. He argued in this way: some people believe that the soul after death passes to another body. Is there the proof of this? Even if this is so, does the soul pass to a living body or a dead body? If a soul moves to another animal's body why should that animal get an alien soul? I we accept that the soul gives life to the lifeless this will contradict the idea that the soul of the dead doesn't disappear. Do souls give birth to different animals? After all, a soul is passing to different phenomena in the end depending on human's deals in the 
previous life, so what will it mean for a soul: a joyful life or torture? As one can see there is a contradiction in the Kardec's description of a spirit.

English spiritists didn't support this definition because of their more materialistic direction. So none of these two directions discloses the genuine essence of a spirit. Although Allan Kardec acknowledged that spirit is immortal, he at the same time supported the view that after human's death his spirit leaves the body and transits to another entity. This is unacceptable explanation of immortality of a spirit. Neither is the view of materialists acceptable because they deny the existence of a spirit. That's why there is a need to testify immortality of spirit.

\section{Conclusions}

Shakarim contemplating about the power of a soul mentioned a thinker Kalestro and his ability to predict, his clairvoyance of future. This proofs that the power of a soul is in ability to see the future.

Shakarim Kudayberdiuly says: "Let's talk about a soul. As I said a soul always exists and doesn't disappear. A soul exists but it can be changed. There are different categories of souls and they can be divided depending their features and character. For example, there are sensitive, curious, clever souls.

In the work "Soul" he described all phenomena happening in the world as purposeful, smart actions. "Competition of the changing world is a result of the smart soul" (Shakarim Kudayberdiuly, 2000). Such a psychological description of a soul as sensitive and smart is very peculiar to Kazakh worldview.

All problems that Shakarim was talking about were taken easily and required common sense. Therefore Shakarim always reiterated his followers that anything can be grasped by mind. He performed simple reasoning when discussed materialists' views. He emphasized with sadness that often a personal opinion of one man can mislead a society.

By and large, Shakarim is firmly based on his mind and reasoning. For him, people must not be differentiated by their rank and authority but by their moral purity. He pointed out that despite clear-cut explanations of the existence of soul the materialistic current prevails. He thought that thinkers who expressed the truth were given no attention.

In conclusion, one can notice that in the work of Shakarim "Three clarities" the problem was elaborated on the socio-psychological basis. He was very critical towards European views on this problem. Therefore, his work is very important today and should be deeply studied.

\section{References}

Apresyan, R. G. (2007). Psychological dictionary (p. 696). Moscow.

Gubskiy, E. F. (2007). Philosophical encyclopedic dictionary. Moscow.

Kardec, A. (1863). The book of spirits. Paris.

Kenjatev, D. T. (2007). Philosophy of Kh. A. Yassawi and his role in the history of Turkic worldview. Doctor of philosophy Dissertation theses. Almaty.

Kont, A. (2006). The system of positive politics. A series of social thoughts. Astana.

Shakarim Kudayberdiuly. (1918). "On nationalism”. Journal "Abay”.

Shakarim Kudayberdiuly. (2000). "Imanym". Almaty: "Arys" Press.

Shakarim Kudayberdiuly. (2000). "Soul”. Almaty: “Arys” Press.

Shakarim. (2008). Encyclopedia.

\section{Copyrights}

Copyright for this article is retained by the author(s), with first publication rights granted to the journal.

This is an open-access article distributed under the terms and conditions of the Creative Commons Attribution license (http://creativecommons.org/licenses/by/3.0/) 